\title{
Plant Growth and Stomatal Responses of Potato Cultivars under High Temperature Stress
}

\author{
A. Sabina, C. Sameena
}

10.18805/IJARe.AF-683

\begin{abstract}
Background: The higher temperatures resulted due to global warming might bring about changed geographical distribution of crops and even in the season. In other words, heat stress is likely to be an eventual challenge for crop production in general and for potatoes in particular. Thus, imparting heat tolerance in potato cultivars is of utmost importance.

Methods: The experiment was conducted in pots and the ambient temperature was approximately $33 \pm 0.5^{\circ} \mathrm{C}$ which constitutes heat stress for potato crop. Potato cultivars namely Kufri Ashoka (relatively heat susceptible) and Kufri Surya (relatively heat tolerant), cultivars, were used in this experiment. The observations were made on the fourth leaf from the top of the mother shoot in potted plants which was fully expanded; data collected were subjected to statistical analysis by using analysis of variance under completely randomized design.

Result: Data recorded on different morphological and stomatal attributes indicate that there was significant difference between susceptible and tolerant cultivars of potato wherein Kufri Surya showed better shoot/root ratio, stomatal density as well as stomata index as compared to Kufri Ashoka.
\end{abstract}

Key words: Heat tolerance, Plant growth, Screening

\section{INTRODUCTION}

Potato, a nutritious crop which can be grown in many environments and could be an important food to help with the world's increasing demand for food due to its growing population. However, the yield of potatoes in the tropics and sub-tropics is less than $1 / 3$ compared to the temperate zones (Kooman,1995). Tuber yield and quality of potato reduces with high temperatures, one of the main hurdles for increasing potato yield in warmer areas and seasons. High temperatures decrease the production of crops as they limit plant growth due to factors such as heat stress and/or reduced partitioning of photo assimilates to potatoes. One important factor for the potato crop is minimal night temperatures as, potato tuberization is decreased when temperatures at night are above $20^{\circ} \mathrm{C}$ and if they are $25^{\circ} \mathrm{C}$ and above, no tuberization will occur. Injuries due to high temperature stress may eventually result in growth suppression, starvation, reduced iron flux and might even result in generation of reactive oxygen species and/or toxic substances (Schoffl et al., 1999; Howarth, 2005).

After exposure to elevated temperature, heat shock proteins are activated; this is known to be an important environmental adaptive strategy in this regard (Feder and Hoffman, 1999, Janni et al., 2020). The tolerance caused due to exposure to so, results in many benefits, such as better photosynthesis, water use and nutrient use efficiency, assimilate partitioning and stability of cell membranes (Camejo et al., 2005; Ahn and Zimmermann, 2006 and Momcilovic and Ristie, 2007). Due to these adaptations, plants are able to grow and develop under heat stress. Successful attempts have already been made to strengthen heat tolerance through traditional crop breeding methods
American University in the Emirates and Amity University, Academic City Dubai, United Arab Emirates.

Corresponding Author: A. Sabina, American University in the Emirates and Amity University, Academic City Dubai, United Arab Emirates. Email: akhtar.sabinaskuast@gmail.com

How to cite this article: Sabina, A. and Sameena, C. (2022). Plant Growth and Stomatal Responses of Potato Cultivars under High Temperature Stress. Indian Journal of Agricultural Research. 56(1): 18-21. DOI: 10.18805/IJARe.AF-683.

Submitted: 09-08-2021 Accepted: 11-11-2021 Online: 22-12-2021

(Ehlers and Hall, 1998, Camejo et al., 2005, Driedonks et al., 2016). There is a huge amount of variation between and within species, this provides an opportunity to improve the tolerance of crops on heat stress through genetic means. So, keeping the above in view research was performed to study the morphological and anatomical parameters with two potato cultivars of diverse nature, namely heat susceptible Kufri Ashoka and heat tolerant Kufri Surya.

\section{MATERIALS AND METHODS}

The experiment was conducted in 2017-2018 and 2018-19 at the Central Potato Research Institute Regional Station, Modipuram Campus. Potato cultivars namely Kufri Ashoka and recently released heat tolerant cultivar Kufri Surya were grown in pots. Kufri Ashoka is an early maturing (70-80 days) cultivar whereas Kufri Surya, which is a cross between LT1 (Male parent) heat tolerant line and the cultivar Kufri Lauvkar (Female parent), is an early maturing cultivar that takes about 75-90 days to mature. The pots were maintained in a completely randomized block design consisting of two rows, 
each of 50 pots per row for individual cultivar. The maximum and minimum temperature during planting time in September ranged from $31-35^{\circ} \mathrm{C}$ and 22 to $25^{\circ} \mathrm{C}$, respectively. All the pots were watered regularly in order to maintain ideal moisture content in the soil. At 45, 60 and 75 days after planting (DAP), samples were collected. One plant/pot was used for taking observations and treated as one replication. Observations were made at various stages of growth and development. Healthy and fully developed shoot was randomly chosen to measure the stem height per plant. Starting from lowermost green part of the stem (near ground) to the youngest leaf was measured as stem height and represented in centimeters. The root length was also measured in centimeters. Root was considered to be started from where the plant was embedded in soil and tissues were white in color. The root length was measured from white part to the last visible finest intact root end in the washed and cleaned uprooted plant sample. The shoot- root ratio was determined by dividing shoot length with root length at each sampling stage. For the stomatal density and stomatal index, the uppermost leaf tissue upper epidermis was taken and fixed in 1:1:1 ratio of formaldehyde, acetic acid and alcohol. On the day of observation these leaf tissues were taken and immersed in Petri plate containing hydrogen peroxide and acetic acid for one hour. Epidermal portion of the leaf was gently peeled off. The peels were mounted in glycine and viewed under microscope (Paul et al., 2007). The parameters namely stomatal density and stomatal index was determined by employing the formula:

Stomatal density $=$ Number of stomata $/ \mathrm{mm}^{2}$ leaf area

$$
\text { Stomatal index }=\frac{\text { Number of stomata }}{\text { Number of epidermal cell }} \times 100
$$

(Mallick et al., 2016)

Data collected during this investigation were subjected to statistical analysis by applying ANOVA test or analysis of variance suggested for the completely randomized design for pot experiments (Gomez and Gomez, 1984).

\section{RESULTS AND DISCUSSION}

The information shown in Table 1 revealed that under heat stress conditions of early season, shoot height generally increased with the age of plant with minimum height $(20.6 \mathrm{~cm})$ at 45 DAP and maximum $(37.0 \mathrm{~cm})$ at 75 DAP. The heat susceptible cultivar Kufri Ashoka produced tallest plants $(37.0$ and $26.8 \mathrm{~cm})$ at 75 DAP $1^{\text {st }}$ and $2^{\text {nd }}$ year whereas the tolerant cultivar Kufri Surya maintained relatively compact canopy and plants were invariably smaller (26.3 and 25.2 $\mathrm{cm}$ ) during $1^{\text {st }}$ and $2^{\text {nd }}$ year, respectively. This morphological difference may be due to the difference in assimilate partitioning do the above ground vegetative parts. It is known that in a normal potato cultivar at high temperature the shoot becomes an important sink for photosynthesis (Basu and Minhas 1991). In general, with the increase in age of crop, root length increased gradually from 45 to 60 DAP and then declined at 75 DAP under heat stress in both the years. Contrary to shoot height, maximum root length was recorded in Kufri Surya at 60 DAP (31.3 and $30.7 \mathrm{~cm}$ ) in comparison to Kufri Ashoka $(27.7$ and $28.2 \mathrm{~cm}$ ). Significant genotypic differences were found in relation to root length as well in heat tolerant and heat susceptible cultivars indicating the potential of this morphological trait for choosing heat tolerant potato clones. In each of the cultivars the root size was reduced at maturity but reduction was more in Kufri Ashoka. Root systems often grow quickly during the earlier stages of growth and achieve maximum growth by mid-season; after which density, root length and root mass decrease as the whole plant matures. Decrease in the size of true root system under higher temperature stress may be largely due to reduction in number and length of true lateral roots (Nagel et al., 2009). Similar finding was reported by Sarquis et al. (1996) that redistribution of food material, rather than reduction are in favor of aerial parts of plants at the cost of underground growth leads to such situation.

Data showed that under heat stress condition of early season (September planted), shoot/root ratio increased with increasing crop age. Shoot root ratio was variably higher in

Table 1: Variations in morphological parameters of heat tolerant and susceptible cultivars of potato under high temperature stress.

\begin{tabular}{|c|c|c|c|c|c|c|}
\hline \multirow{2}{*}{ Cultivar } & \multicolumn{3}{|c|}{$1^{\text {st }}$ year } & \multicolumn{3}{|c|}{$2^{\text {nd }}$ year } \\
\hline & 45 & 60 & 75 & 45 & 60 & 75 \\
\hline \multicolumn{7}{|c|}{ Shoot length (cm) } \\
\hline Kufri Ashoka & 31.8 & 33.7 & 37.0 & 31.7 & 33.9 & 36.8 \\
\hline Kufri Surya & 20.6 & 23.2 & 26.3 & 21.4 & 23.0 & 25.2 \\
\hline LSD $5 \%$ & 2.6 & 2.3 & 3.1 & 3.3 & 4.1 & 3.1 \\
\hline \multicolumn{7}{|c|}{ Root length (cm) } \\
\hline Kufri Ashoka & 27.3 & 27.7 & 26.8 & 26.3 & 28.2 & 29.1 \\
\hline Kufri Surya & 29.1 & 31.3 & 20.7 & 26.7 & 30.7 & 21.0 \\
\hline LSD $5 \%$ & 0.6 & 1.7 & 0.8 & 4.2 & 1.3 & 2.3 \\
\hline \multicolumn{7}{|c|}{ Shoot and root ratio } \\
\hline Kufri Ashoka & 1.2 & 1.2 & 1.4 & 1.2 & 1.2 & 1.3 \\
\hline Kufri Surya & 0.7 & 0.7 & 1.3 & 0.8 & 0.7 & 1.2 \\
\hline LSD $5 \%$ & 0.1 & 0.2 & 0.2 & NS & 0.2 & 0.2 \\
\hline
\end{tabular}


Plant Growth and Stomatal Responses of Potato Cultivars under High Temperature Stress

Table 2: Variations in stomatal numbers of heat tolerant and susceptible cultivars of potato under high temperature stress.

\begin{tabular}{|c|c|c|c|c|c|c|}
\hline \multirow{2}{*}{ Cultivar } & \multicolumn{3}{|c|}{$1^{\text {st }}$ year } & \multicolumn{3}{|c|}{$2^{\text {nd }}$ year } \\
\hline & 45 & 60 & 75 & 45 & 60 & 75 \\
\hline \multicolumn{7}{|c|}{ Stomatal density (no./mm²) } \\
\hline Kufri Ashoka & 24.7 & 20.0 & 16.7 & 23.3 & 18.7 & 15.3 \\
\hline Kufri Surya & 31.7 & 28.3 & 26.3 & 30.0 & 27.0 & 24.0 \\
\hline LSD $5 \%$ & 1.3 & 1.9 & 2.7 & 1.9 & 1.9 & 1.9 \\
\hline \multicolumn{7}{|c|}{ Stomatal index (\%) } \\
\hline Kufri Ashoka & 7.9 & 7.0 & 5.9 & 92.8 & 96.3 & 94.2 \\
\hline Kufri Surya & 9.4 & 8.9 & 8.8 & 9.2 & 8.6 & 8.0 \\
\hline LSD 5\% & 0.3 & 0.7 & 0.9 & 0.7 & 0.5 & 0.8 \\
\hline
\end{tabular}

Kufri Ashoka (1.2, 1.2 and 1.4 at 45, 60 and 75 DAP, respectively) as against Kufri Surya having values of $0.7,0.7$ and 1.3 at respective ages of the plants during first year of observation. Trend for shoot/root ratio was similar during the next year as well. These observations indicated a considerable difference in the two cultivars with respect to their plant type particularly at 45 and 60 DAP. Differences are found among cultivars in their response to heat stress, in general, day maximum temperature $\left(\geq 25-30^{\circ} \mathrm{C}\right)$ reduces the net assimilation rate, increases stem and branch length while reduced to leaf size leads to less leaf area (Manrique 1990).

Data presented in Table 2 show that Kufri Surya recorded higher stomatal density $\left(31.7 / \mathrm{mm}^{2}\right.$ and index $(9.4 \%)$ at 45 DAP as compared to Kufri Ashoka $\left(24.7 / \mathrm{mm}^{2}\right.$ at and $\left.7.9 \%\right)$. Stomatal density and stomatal index decreased with advancing crop age (Schletz, 2008; Reich,1984). At 75 DAP minimum values were recorded for stomatal density and stomatal index in Kufri Ashoka $\left(16.7 \mathrm{~mm}^{2}\right.$ and $5.9 \%$, respectively) as against Kufri Surya $\left(26.3 / \mathrm{mm}^{2}\right.$ and $\left.8.8 \%\right)$.

The results suggested that Kufi Surya maintained invariably higher stomatal density and stomatal index from 45 to 75 DAP as against Kufri Ashoka. The number of stomata was more in developing leaves and less in mature leaves of both the cultivars. High stomatal densities in plants help increase conductance as well as photosynthetic gasses exchange before the eventual senescence of mature leaves. The higher stomatal density in Kufri Surya could have been beneficial for higher assimilation rate for better cooling through enhanced transpiration.

Significant difference was found between heat susceptible Kufri Ashoka and heat tolerant cultivar Kufri Surya indicating the potential of these morphological traits for selecting heat tolerant potato clones.

\section{REFERENCES}

Ahn, Y.J. and Zimmerman, J.L. (2006). Introduction of the carrot HSP17.7 into potato (Solanum tuberosum L.) enhances cellular membrane stability and tuberization in vitro. Plant, Cell and Environment. 29: 95-104.

Basu, P.S. and Manhas, J.S. (1991). Heat tolerance and assimilate transport in different potato genotypes. Journal of Experimental Botany. 42: 861-866.
Camejo, D., Rodríguez, P., Morales, M.A., Dell'Amico, J.M., Torrecillas, A. and Alarcon, J.J. (2005). High temperature effects on photosynthetic activity of two tomato cultivars with different heat susceptibility. Journal of Plant Physiology. 162: 281-289.

Driedonks, N., Rieu, I. and Vriezen, W.H. (2016). Breeding for plant heat tolerance at vegetative and reproductive stages. Plant Reproduction. 29: 67-79.

Ehlers, J.D. and Hall, A.E. (1998). Heat tolerance of contrasting cowpea lines in short and long days. Field Crops Research. 55: 11-21.

Feder, M.E. and Hofmann, G.E. (1999). Heat-shock proteins, molecular chaperones and the stress response: Evolutionary and ecological physiology. Annual Review of Physiology. 61: 243-282.

Gomez, K.A. and Gomez, A.A. (1984). Statistical Procedures for Agricultural Research ( $2^{\text {nd }}$ Eds. $)$, John Wiley and Sons. New York.

Howarth, C.J. (2005). Genetic Improvements of Tolerance to High Temperature. In: Abiotic Stresses: Plant Resistance through Breeding and Molecular Approaches. [M. Ashraf and P.J.C. Harris (Eds.)], New York: Howarth Press Inc.

Janni, M., Gulli, M., Elena, M., Marta, M., Babu, V., Henry, T.N. and Nelson, M. (2020). Molecular and genetic bases of heat stress responses in crop plants and breeding for increased resilience and productivity. Journal of Experimental Botany. 71: $3780-3802$.

Kooman, P.L. (1995). Yielding ability of potato crops as influenced by temperature and daylength. Ph.D. Thesis, Wageningen Agricultural University, Wageningen, The Netherlands.

Mallick, M., Awasthi, O.P., Paul, V., Verma, M.K. and Jha, G. (2016). Effect of physical and chemical mutagens on leaf sclerophylly and stomatal characteristics of Kinnow mandarin mutants. Indian Journal of Horticulture. 73: 291293.

Manrique, L.A. (1990). Estimating soil surface temperatures under different crop covers in Hawaii. Communications in Soil Science and Plant Analysis. 21: 2105-2117.

Momcilovic, I. and Ristic, Z. (2007). Expression of chloroplast protein synthesis elongation factor, EF-Tu, in two lines of maize with contrasting tolerance to heat stress during early stages of plant development. Journal of Plant Physiology. 164: 90-99. 
Nagel, K.A., Kastenholz, B., Jahnke, S., Van, D.D., Aach, T., Muhlich, M., Truhn, D., Scharr, H., Terjung, S., Walter, A. and Schurr, U. (2009). Temperature responses of roots: Impact on growth, root system architecture and implications for phenotyping. Functional Plant Biology. 36: 947-959.

Paul, V., Malik, S.K. and Srivastava, G.C. (2007). Intervarietal differences in the surface morphology and anatomy of mango (Mangifera indica L.) fruits. Phytomorphology. 57: 211-220.

Reich, P.B. (1984). Loss of stomatal function in ageing hybrid poplar leaves. Annals of Botany. 53(5): 691-698.
Sarquis, J.I., González, H. and Bernal-Lugo, I. (1996). Response of two potato clones ( $S$. tuberosum L.) to contrasting temperature regimes in the field. American Potato Journal. 73: $285-300$.

Schletz, R. (2008). Stomata densities of developing and mature leaves of geraniums. ESSAI. 6: 129-132.

Schoffl, F., Prandl, R. and Reindl, A. (1999) Molecular Responses to Heat Stress. In: Molecular Responses to Cold, Drought, Heat and Salt Stress in Higher Plants. [K. Shinozaki and K.Yamaguchi-Shinozaki (Eds.)], Austin, Texas: R.G. Landes Co. (pp. 81-98), 